\title{
Neural tissue engineering using embryonic and induced pluripotent stem cells
}

Stephanie M Willerth*1,2,3

\begin{abstract}
With the recent start of the first clinical trial evaluating a human embryonic stem cell-derived therapy for the treatment of acute spinal cord injury, it is important to review the current literature examining the use of embryonic stem cells for neural tissue engineering applications with a focus on diseases and disorders that affect the central nervous system. Embryonic stem cells exhibit pluripotency and thus can differentiate into any cell type found in the body, including those found in the nervous system. A range of studies have investigated how to direct the differentiation of embryonic cells into specific neural phenotypes using a variety of cues to achieve the goal of replacing diseased or damaged neural tissue. Additionally, the recent development of induced pluripotent stem cells provides an intriguing alternative to the use of human embryonic stem cell lines for these applications. This review will discuss relevant studies that have used embryonic stem cells to replicate the tissue found in the central nervous system as well as evaluate the potential of induced pluripotent stem cells for the aforementioned applications.
\end{abstract}

\section{Introduction}

The human nervous system can be divided into two major components: the central nervous system (CNS) and the peripheral nervous system [1]. The CNS consists of the brain and the spinal cord with the blood-brain barrier restricting the types of biomolecules that can reach these organs [2]. The majority of neural tissue found in the CNS consists of two cell types: neuronal cells and glial cells. Neurons serve as the main information transmitting unit of the nervous system, which

\footnotetext{
*Correspondence: willerth@uvic.ca

'Department of Mechanical Engineering, University of Victoria, PO Box 3055,

STN CSC, Victoria, British Columbia, V8W 3P6, Canada

Full list of author information is available at the end of the article
}

can be classified as either sensory, allowing them to detect stimuli from the environment, or motor, responsible for the generation of movement through signaling with muscle tissue [3]. Glial cells encompass a number of different types of support cells, including astrocytes and oligodendrocytes found in the CNS $[4,5]$. This review will discuss the use of embryonic stem (ES) cell therapy as a method of treating injuries and diseases that inflict damage to the CNS. These studies are particularly relevant now as the first human ES-cell-derived therapy is currently being evaluated in clinical trials as a potential method for treating spinal cord injury (SCI) [6].

ES cells possess two hallmark characteristics: the ability to self-renew and pluripotency [7]. The pluripotent nature of ES cells allows them to generate the cells found in neural tissue, including neurons and glia. As a result, ES-cell-based regeneration strategies have been investigated for a number of diseases as well as for repairing mechanically damaged nerve tissue. While many other types of stem cells have been evaluated for their potential to promote neural repair, this review will focus specifically on the attempts made with ES cells as this work will be most applicable to developing therapies using induced pluripotent stem (iPS) cells. First generated in 2006, iPS cells are produced from adult somatic cells, such as skin cells, by inducing specific factors that restore pluripotency [8-10] (Figure 1). The recent generation of these cell lines serves as an exciting alternative to traditional ES cell lines and recent research using iPS cells will also be critically examined in terms of the future of stem-cellbased therapies for repairing neural tissue.

Many of the studies detailed in this review use mouse ES cells as a model system for studying cell behavior with the goal of translating this knowledge to human ES cells. While this approach does have merit, it is important to note some of the differences between mouse and human ES cell lines. One of the major differences is that mouse ES cells can be maintained in the presence of leukemia inhibitory factor (LIF) on gelatin substrates in a relatively cost effective manner while human ES cells are cultured either on a feeder layer of cells or on a Matrigel surface in the presence of defined media [11]. Mouse and human ES cells differ in protein expression patterns, including the 


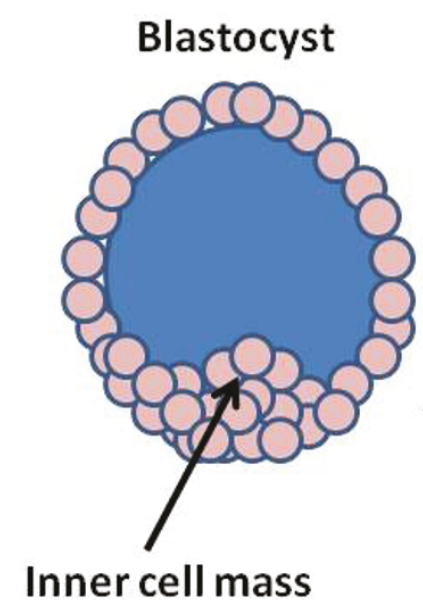

Yamanaka factors
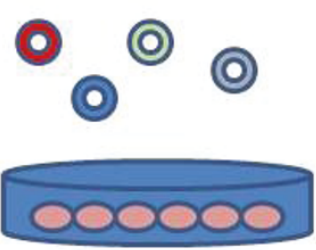

Somatic cells
Generation of embryonic stem cell line $\searrow$

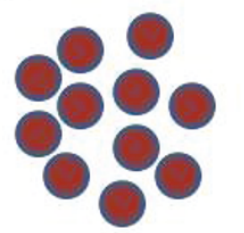

Neuron

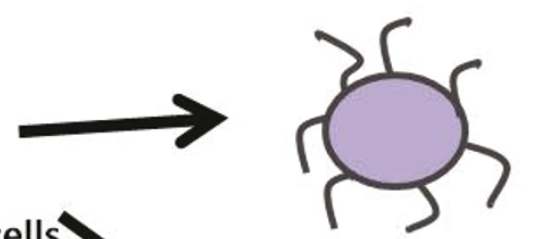

Oligodendrocyte
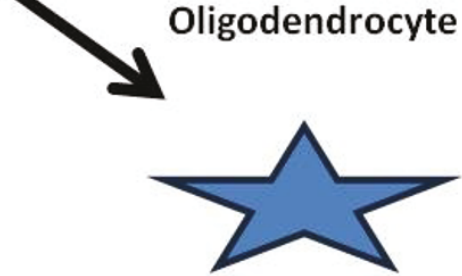

Astrocyte

Figure 1. The use of pluripotent stem cells for engineering neural tissue. The diagram compares the derivation of embryonic stem cell lines from the inner cell mass of the blastocyst and how induced pluripotent stem cells are derived from somatic cells by induction of the Yamanaka factors. These pluripotent stem cells can then be directed to differentiate into the three main cell types found in the central nervous system (neurons, oligodendrocytes, and astrocytes).

signaling pathways that regulate differentiation and the markers that indicate pluripotency [12]. For example, undifferentiated mouse ES cells express stage-specific embryonic antigen (SSEA)-1 while undifferentiated human ES cells express the SSEA-3 and SSEA-4 markers [13]. Thus, the information gained in mouse ES cell studies does not always directly translate to human ES cell lines due to these intrinsic differences.

Both human ES and iPS cells exhibit high variability between different cell lines as illustrated by a recent study published in Cell that mapped the genome-wide DNA methylation patterns and gene expression for 20 ES and 12 iPS cell lines [14]. They used the information obtained from the ES cell lines as a reference to evaluate the expression patterns of the iPS cell lines to see if they fell within an acceptable range of 'stemness'. Another study used transcriptional profiling analysis to show that the iPS cell lines have residual gene expression from the donor cells after reprogramming, with certain donor cells being reprogrammed more efficiently [15]. Both of these studies illustrate the need for defined standards to use for evaluating newly derived ES and iPS cell lines to determine their suitability for clinical applications.

\section{Embryonic stem-cell-based therapies for neural tissue replacement}

Many different studies have used ES cells to generate replacement neural tissue for a variety of diseases and disorders (Table 1). One of the major considerations when working with ES cells is how to induce them to differentiate into the specific neural phenotypes necessary for treating the particular application. Regenerationpromoting strategies can include directly deriving the desired cell type to be replaced or generating supporting glial cells that secrete factors to help restore lost functionality. In terms of differentiation protocols, the most desirable methods would produce a highly purified population of specific cellular phenotypes for transplantation as any undifferentiated ES cell clusters remaining can proliferate in an uncontrolled fashion, leading to teratoma formation [16]. To avoid teratoma formation, many different methods have been investigated to 


$\begin{aligned} & \text { Table 1. The use of embryonic stem and induced } \\
& \text { pluripotent stem cell derived therapies for neural tissue } \\
& \text { engineering applications }\end{aligned}$
\begin{tabular}{lll}
\hline Disease/disorder & Cell lines & References \\
\hline Traumatic brain injury & Mouse embryonic stem cells & {$[24-27]$} \\
& & \\
Parkinson's disease & Mouse embryonic stem cells & {$[34,35,40]$} \\
& Human embryonic stem cells & {$[36-39,41]$} \\
& Mouse induced pluripotent cells & {$[88]$} \\
& & \\
Huntington's disease & Human embryonic stem cells & {$[47-49]$} \\
& & {$[51,52]$} \\
Alzheimer's disease & Mouse embryonic stem cells & \\
& & {$[54-58,60,62$,} \\
Spinal cord injury & Mouse embryonic stem cells & $64,68,77-79,81]$ \\
& & {$[65,67,69,70$,} \\
& Human embryonic stem cells & $72,74,82]$ \\
& & {$[87,88]$} \\
\hline
\end{tabular}

minimize the transplantation and survival of undifferentiated ES cells [17]. These methods include using cell sorting to isolate a specific progenitor population and performing extensive differentiation protocols to ensure only mature cells are transplanted. Other ways to eliminate the undifferentiated ES cell populations after transplantation include the development of an ES cell line modified with an inducible suicide gene expressed under a promoter element used to maintain 'stemness' and the use of targeted anti-human ES cell antibodies that induce apotosis of undifferentiated ES cells [18-20].

While specific protocols for directing stem cell differentiation into neural lineages will not be reviewed in depth here, several reviews on the subject describe these processes in more detail [21,22]. When developing EScell-based treatments for neural diseases and disorders, it is important to consider what specific cell populations could potentially restore lost function. For certain neurodegenerative disorders that affect specific neuronal populations, the goal is to transplant a highly differentiated mature population of neurons to replace the lost cells. For promoting recovery after traumatic CNS injury, a variety of ES-cell-based therapies have been explored as neural progenitors could potentially secrete regenerationpromoting factors while the transplantation of ES-cellderived neurons and oligodendrocytes to restore the lost mature cellular populations has also been studied. The method of transplanting the cells in the desired location in the CNS should also be carefully evaluated to ensure cell viability and prevent unwanted differentiation. Other relevant issues relating to ES-cell-based therapies include the potential of the transplanted cells to induce an immune response. These issues will be discussed along with the relevant studies for each of the following diseases and disorders.

\section{Traumatic brain injury}

It is estimated that 3.2 million people in the United States currently suffer from reduced function after hospitalization as a result of traumatic brain injury (TBI) [23]. The impact and resulting lesion from TBI often results in cognitive, sensory, motor, and emotional impairments. Several studies have investigated the use of ES-cellderived therapies, specifically the transplantation of neural progenitors and undifferentiated ES cells, as a way of treating TBI with the hope of alleviating the aforementioned symptoms as these cells could secrete factors that would induce regeneration. In one of the first studies to investigate such a strategy, neural progenitors produced by treating mouse ES cells with retinoic acid were transplanted into the lesion site one week after administration of a cortical impact injury [24]. They found that these cells were able to prevent the formation of necrotic cavities that would normally occur after injury and were able to improve the sensorimotor function. Another group showed transplanted mouse ES cells migrated to the injury sites consisting of lesions induced by fluid injection in the mouse brain, suggesting that the damaged brain tissue secreted factors to induce ES cell migration [25]. In a similar study, the ability of undifferentiated mouse ES cells to promote recovery after TBI was evaluated [26]. The animals that received the ES cells performed better on the Rotorod test, measuring the animal's ability to stay on a moving rod, and had better Neuroscores, reflecting an improvement in their neuromotor function. However, they observed tumor formation in two of the ten animals receiving the cells, illustrating a limitation of using undifferentiated ES cells as a therapy. In a follow-up study, they reported that the inflammatory response associated with TBI impaired ES cell survival and integration after implantation into injured rat brain [27]. These studies illustrate the potential of ES cell therapies for the treatment of TBI, but much work remains before such therapies will be suitable for evaluation in clinical trials.

\section{Parkinson's disease}

The loss of dopaminergic neurons located in the substantia nigra is one of the major hallmarks of Parkinson's disease (PD) [28]. These neurons secrete dopamine, which regulates cortical and thalamic activity. Loss of these dopamine neurons in the substantia nigra results in motor dysfunction, including tremor, rigidity, and bradykinesia, as well as non-motor symptoms, including anxiety and depression. The current treatment for PD consists of the drug levodopa, often referred to as L-dopa, 
which is a dopamine precursor that can cross the bloodbrain barrier, where it is then metabolized into dopamine [29]. However, long-term use of levodopa leads to more motor function dysregulation [30]. Additionally, the transplantation of fetal tissue as a method of replacing the lost dopamine neurons has also been investigated, but the most recent clinical trials did not show any benefit to receiving this treatment [31-33]. The goal of ES-cell-based therapies for PD is to generate a highly defined, dopaminergic neuron population suitable for transplantation into the substantia nigra.

Many groups have investigated the use of ES-cellderived dopaminergic neurons for their potential to treat $\mathrm{PD}$ as an alternative to the current standard of care. One group implanted undifferentiated mouse ES cells directly into the mid-brain, where the cells differentiated into functional dopaminergic neurons and promoted functional recovery in a rat model of PD induced by injections of 6-hydroxydopamine [34]. Another study developed an extensive five step protocol for generating dopaminergic neurons from mouse ES cells and showed that transplantation of these cells improved function in the same PD rat model [35]. Similar studies were also performed using human ES-cell-derived dopaminergic neurons and showed that transplantation of these cells into a rat model of PD produced similar improvements in function [36-39]. Other groups have shown that co-cultures of ES cells with astrocytes and stromal cells induces differentiation into dopaminergic neurons [37,40,41]. Finally, a recent study developed an efficient protocol for large scale production of dopaminergic neurons from human ES cells that reduces the potential for tumor formation, bringing this therapy closer to standards required for clinical testing [39].

\section{Huntington's disease}

Huntington's disease (HD) is a rare, inherited neurodegenerative disorder characterized by a loss of medium spiny projection neurons in the striatum [42]. Symptoms include loss of muscular coordination along with progressive cognitive decline. Many clinical studies have investigated the transplantation of fetal-derived tissue into the brain as a potential treatment for HD [43-46] and ES cells provide an alternative to the use of such tissues by providing an alternative way to replace the lost neuronal population.

One study induced human ES cells to differentiate into neural progenitors and then transplanted these cells into a rat model of HD induced using quinolinic acid [47]. The animals receiving the treatment performed better on an apomorphine-induced rotation test compared to sham treated animals and no tumor formation was observed. While they did observe neuronal differentiation of the transplanted progenitors, they did not investigate the mechanism behind the observed recovery to determine if it was due to the secretion of factors that preserved the existing cells or if the transplanted cells were contributing to the functional recovery. A second study utilized a three step protocol to induce human ES cells to differentiate specifically into striatal spiny neurons for transplantation [48]. While the initial results were promising, after 13 weeks, the grafts overgrew the implantation site, leading to deleterious side effects. However, these grafts did not contain undifferentiated ES cells, but the regions of overgrowth did contain nestin-positive neural progenitor cells. A different study showed that treatment of neural progenitors derived from human ES cells with the protein Noggin enhanced neuronal differentiation post-implantation in a rat model of HD [49]. These studies demonstrate the viability of using ES-cell-derived therapies as a way to replace the lost neuronal populations due to HD. However, the issue of graft overgrowth as well as determining how these transplanted cells contribute to function recovery will have to be addressed and characterized before these therapies can be translated to the clinic.

\section{Alzheimer's disease}

Similar to HD, Alzheimer's disease (AD) is another neurodegenerative disease that tends to affect people over the age of 65 years. The clinical symptoms of $\mathrm{AD}$ include progressive cognition deterioration due to the loss of cholinergic neurons [50]. In terms of histology, $\mathrm{AD}$ is associated with the appearance of amyeliod plaques and neurofibrillary tangles in the brain. Many groups have investigated the use of ES-cell-derived therapies as a means of treating $\mathrm{AD}$ in pre-clinical models by differentiating ES cells into cholinergic neurons as this cell population is one the most affected by AD.

One group derived neurospheres from mouse ES cells and transplanted the resulting cells into a mouse model of $\mathrm{AD}$ [51]. These cells differentiated into choline acteyltransferase-positive neurons and reduced memory deterioration compared to control mice that received undifferentiated ES cells. The control mice receiving the undifferentiated ES cell transplants also showed tumor formation and significant memory deterioration. Another study took a similar approach to differentiating mouse ES cells and also examined the effect of adding the growth factor sonic hedgehog (Shh) during the neurosphere formation step. They observed that the differentiation of neural progenitors into cholinergic neurons was enhanced by priming the neurospheres with Shh and the treated animals that received these cells showed a significant improvement in memory as indicated by performance in a water maze test [52]. These studies provide preliminary evidence for an ES-cell-based therapy for $\mathrm{AD}$, but such results would need to be repeated with 
human ES cells in pre-clinical testing to determine the viability of such a strategy.

\section{Spinal cord injury}

The complex arrangement of neurons, oligodendrocytes, and astrocytes allow the spinal cord to coordinate movement and sensation between the brain and the limbs and disruption of this structure due to mechanical injury can result in paralysis [53]. The extent of paralysis depends on the degree of trauma and the location of the injury in the spinal cord. The initial mechanical injury triggers a secondary cascade of events and damage from both of these processes must be addressed when designing a suitable therapeutic repair strategy. ES-cell-based therapies for the treatment of SCI have focused on generating both neurons and oligodendrocytes to promote recovery after injury.

The McDonald group [54] transplanted retinoic-acidtreated ES cells into a rat model of SCI and these cells were able to survive and differentiate into neurons, oligodendrocytes, and astrocytes while promoting recovery as indicated by regained hind limb function. Other groups using similar approaches observed improvements in motor and sensory function after transplantation of pre-differentiated mouse ES cells [55-57]. Another group showed that transplantation of bone marrow stromal cells along with retinoic-acid-treated mouse ES cells prevented tumor formation in a rat model of SCI [58]. Other studies have used genetically modified ES cell lines to improve cell survival and differentiation after transplantation, but the use of virus-mediated transfection methods limit the feasibility of such approaches [59-62].

More recent work has focused on the production of specific cellular populations from ES cells for treatment of SCI. Many groups have chosen to differentiate ES cells into motor neurons as a therapeutic strategy. One approach involved inducing mouse ES cells to differentiate into motor neurons using a combination of retinoic acid and Shh and transplanted these cells into a virusmediated rat model of SCI, with approximately $25 \%$ of these cells surviving one month after transplantation [63]. Another group transplanted ES-cell-derived motor neurons along with olfactory ensheathing cells into a rat model of SCI and observed partial functional recovery [64]. The Keirstead group has shown that motor neurons derived from human ES cells can also promote functional recovery after SCI in a rat model [65]. This strategy also holds potential for the treatment of amyotrophic lateral sclerosis, a neurodegenerative disease characterized by the loss of motor neurons [66].

The other major therapeutic strategy has involved differentiating ES cells into oligodendrocytes for treating SCI [67-74]. One of the most promising approaches to treatment of SCI involves differentiating human ES cells into oligodendrocyte precursors using an extensive 42-day differentiation protocol [71] and then transplanting these cells into the site of SCI [70,72-74]. This therapy showed promising results in pre-clinical trials as these oligodendrocyte precursors differentiated into mature oligodendrocytes, promoting functional recovery in two distinct models of SCI $[72,74]$. This therapy has become the first human ES-cell-derived therapy to be evaluated in clinical trials [6], with the first patient having already been enrolled [75]. The Keirstead group [65] has also begun researching the effects of transplanting motor neuron progenitors into the injured rat spinal cord with some promising results.

Several groups have used tissue engineering approaches that combine biomaterial scaffolds with ES cells for the treatment of SCI. The Sakiyama-Elbert group [76-81] has used a fibrin-based scaffold to deliver growth factors that promote ES cells to differentiate into neurons and oligodendrocytes and this approach has been shown to enhance functional recovery in a rat model of SCI. The Baharvand group [82] has investigated the transplantation of neural progenitors derived from human ES cells inside of collagen scaffolds for the treatment of SCI and this approach also resulted in an increase in locomotor function post-transplantation. Another group developed electrospun poly $(\varepsilon)$-caprolactone scaffolds, which support mouse ES cell culture and promoted differentiation into nestin-positive neural progenitors in an in vitro setting [83]. Many other biomaterials have been investigated for the treatment of SCI, but not in combination with stem cells $[84,85]$.

\section{Reprogramming somatic cells and the potential for engineering neural tissue}

As mentioned in the Introduction, the recent development of iPS cells provides an exciting alternative to the use of ES cells. These cells are generated from somatic cells, such as fibroblasts, by upregulating the expression of specific genes (Oct3/4, Sox2, c-Myc, and Klf4) that restore pluripotency $[9,10]$. Unlike traditional ES cell lines, the use of iPS cells allows for generation of pluripotent cell lines without the use of embryos as well as for the production of patient-specific iPS cell lines, which should reduce the risk of rejection after transplantation.

Several studies have investigated iPS cells and their potential for differentiating into neural phenotypes. A recent study demonstrated that neural differentiation in human iPS cells uses the same transcription networks as traditional human ES cell lines [86]. They also observed lower differentiation efficiency and increased variability compared to ES cells, suggesting that more efficient differentiation protocols may need to be developed to fully utilize the potential of iPS cells (Figure 2). In work also done by the Yamanaka lab [87], 36 mouse iPS cell 


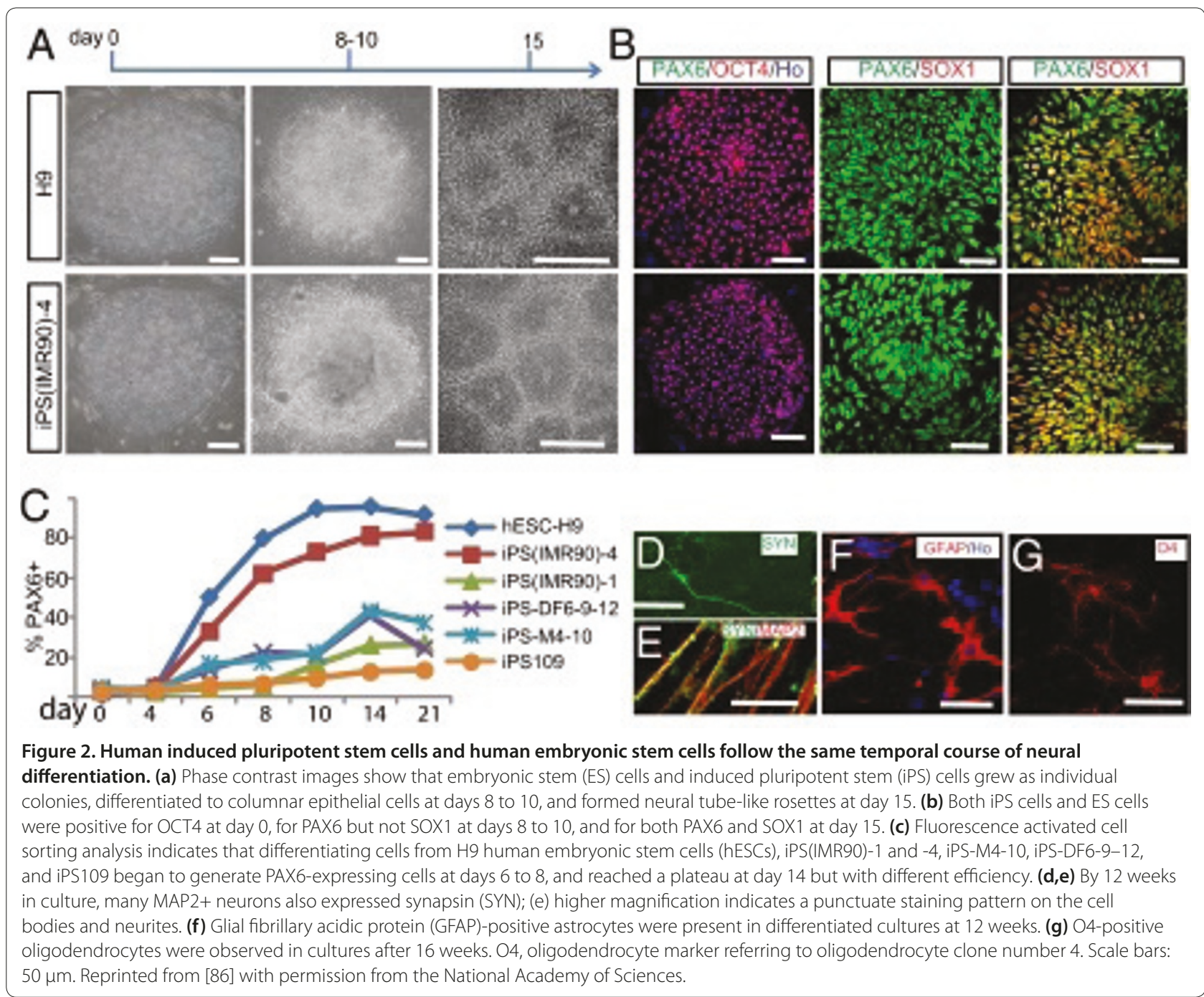

lines were evaluated to determine their potential for generating neural phenotypes after secondary neurosphere formation as well as their potential safety for transplantation as indicated by teratoma formation in an in vivo setting. After an induction period using retinoic acid, these cell lines demonstrated the ability to differentiate into the three cell types found in the CNS (neurons, oligodendrocytes, and astrocytes) and certain iPS cell lines did not form teratomas after implantation, leading them to be classified as a 'safe' cell line. In a follow-up study, neural progenitor cells derived from 'safe' iPS cell lines were implanted into both uninjured spinal cord tissue and a pre-clinical model of SCI in mice [88]. In the uninjured mice, the cells differentiated into neurons and glia, while in the injured animals, these cells differentiated into mature oligodendrocytes and promoted functional recovery in the hind limbs of mice. Other work has derived neurons from iPS cells, which were shown to promote functional recovery in a rat model of PD [89].
These studies indicate the ability of iPS cells to differentiate into neural phenotypes, illustrating their potential as an alternative to the use of traditional ES cell lines. The generation of 'safe', non-teratoma-forming cell lines serves as an added potential benefit of using iPS cells.

An alternative approach to differentiating pluripotent stem cells is to directly convert one mature cell type into the desired cell type by manipulating cell signaling pathways. The Wernig group [90] recently demonstrated that mouse embryonic fibroblasts can be directly converted to neurons if the appropriate factors were expressed, offering a potential method of engineering neural tissue without the use of pluripotent stem cells. Much work remains to be done to determine the feasibility of such an approach for clinical applications.

\section{Conclusion}

Overall, a large body of work exists showing the potential of using pluripotent stem cells to produce replacement 
tissue for the CNS as discussed in this review. The current evaluation of oligodendrocytes derived from human ES cells shows the promise of this technology for the treatment of SCI and other neurological disorders and diseases while the generation of iPS cell lines now allows for generation of patient-specific neural tissue derived from pluripotent stem cells. Additionally, the recent work from the Wernig group showing the direct conversion of somatic cells into neurons provides an intriguing alternative to differentiating pluripotent stem cells as a means of replacing lost neural tissue.

\section{Abbreviations}

$A D$, Alzheimer's disease; CNS, central nervous system; ES, embryonic stem; HD, Huntington's disease; iPS, induced pluripotent stem; PD, Parkinson's disease; $\mathrm{SCl}$, spinal cord injury; Shh, sonic hedgehog; TBI, traumatic brain injury.

\section{Competing interests}

The author declares that she has no competing interests.

\section{Author details}

'Department of Mechanical Engineering, University of Victoria, PO Box 3055, STN CSC, Victoria, British Columbia, V8W 3 P6 Canada. ${ }^{2}$ Division of Medical Sciences, University of Victoria, PO Box 3055, STN CSC, Victoria, British Columbia, V8W 3P6, Canada. International Collaboration on Repair Discoveries (iCORD), Vancouver, British Columbia, V8W 3P6, Canada.

\section{Published: 15 April 2011}

\section{References}

1. Greg Hall D: Fundamentals of neurobiology. Toxicol Pathol 2010, 39:19-21.

2. Roux F, Couraud PO: Rat brain endothelial cell lines for the study of bloodbrain barrier permeability and transport functions. Cell Mol Neurobiol 2005, 25:41-58.

3. Parker D: Neuronal network analyses: premises, promises and uncertainties. Philos Trans R Soc Lond B Biol Sci 2010, 365:2315-2328.

4. Madduri S, Gander B: Schwann cell delivery of neurotrophic factors for peripheral nerve regeneration. J Peripher Nerv Syst 2010, 15:93-103.

5. Benarroch EE: Central neuron-glia interactions and neuropathic pain: overview of recent concepts and clinical implications. Neurology 2010, 75:273-278.

6. World's first clinical trial of human embryonic stem cell therapy cleared. Regen Med 2009, 4:161

7. Thomson JA, Itskovitz-Eldor J, Shapiro SS, Waknitz MA, Swiergiel JJ, Marshall VS, Jones JM: Embryonic stem cell lines derived from human blastocysts. Science 1998, 282:1145-1147.

8. Wernig M, Meissner A, Foreman R, Brambrink T, Ku M, Hochedlinger K, Bernstein $B E$, Jaenisch R: In vitro reprogramming of fibroblasts into a pluripotent ES-cell-like state. Nature 2007, 448:318-324.

9. Takahashi K, Tanabe K, Ohnuki M, Narita M, Ichisaka T, Tomoda K, Yamanaka S: Induction of pluripotent stem cells from adult human fibroblasts by defined factors. Cell 2007, 131:861-872.

10. Takahashi K, Yamanaka S: Induction of pluripotent stem cells from mouse embryonic and adult fibroblast cultures by defined factors. Cell 2006, 126:663-676.

11. Ludwig TE, Levenstein ME, Jones JM, Berggren WT, Mitchen ER, Frane JL, Crandall LJ, Daigh CA, Conard KR, Piekarczyk MS, Llanas RA, Thomson JA: Derivation of human embryonic stem cells in defined conditions. Nat Biotechnol 2006, 24:185-187.

12. Rao M: Conserved and divergent paths that regulate self-renewal in mouse and human embryonic stem cells. Dev Bio/ 2004, 275:269-286.

13. Koestenbauer S, Zech NH, Juch H, Vanderzwalmen P, Schoonjans L, Dohr G: Embryonic stem cells: similarities and differences between human and murine embryonic stem cells. Am J Reprod Immuno/ 2006, 55:169-180.

14. Bock C, Kiskinis E, Verstappen G, Gu H, Boulting G, Smith ZD, Ziller M, Croft GF, Amoroso MW, Oakley DH, Gnirke A, Eggan K, Meissner A: Reference maps of human ES and iPS cell variation enable high-throughput characterization of pluripotent cell lines. Cell 2011, 144:439-452.
15. Ghosh Z, Wilson KD, Wu Y, Hu S, Quertermous T, Wu JC: Persistent donor cell gene expression among human induced pluripotent stem cells contributes to differences with human embryonic stem cells. PLoS One 2010, 5:e8975.

16. Lees JG, Lim SA, Croll T, Williams G, Lui S, Cooper-White J, McQuade LR, Mathiyalagan B, Tuch BE: Transplantation of 3D scaffolds seeded with human embryonic stem cells: biological features of surrogate tissue and teratoma-forming potential. Regen Med 2007, 2:289-300.

17. Fong CY, Gauthaman $K$, Bongso A: Teratomas from pluripotent stem cells: A clinical hurdle. J Cell Biochem 2010, 111:769-781.

18. Choo AB, Tan HL, Ang SN, Fong WJ, Chin A, Lo J, Zheng L, Hentze H, Philp RJ, Oh SK, Yap M: Selection against undifferentiated human embryonic stem cells by a cytotoxic antibody recognizing podocalyxin-like protein-1. Stem Cells 2008, 26:1454-1463.

19. Tan HL, Fong WJ, Lee EH, Yap M, Choo A: mAb 84, a cytotoxic antibody that kills undifferentiated human embryonic stem cells via oncosis. Stem Cells 2009, 27:1792-1801.

20. Schuldiner M, Itskovitz-Eldor J, Benvenisty N: Selective ablation of human embryonic stem cells expressing a "suicide" gene. Stem Cells 2003, 21:257-265.

21. Conti L, Cattaneo E: Neural stem cell systems: physiological players or in vitro entities? Nat Rev Neurosci 2010, 11:176-187.

22. Suter DM, Krause KH: Neural commitment of embryonic stem cells: molecules, pathways and potential for cell therapy. J Pathol 2008, 215:355-368.

23. Corrigan JD, Selassie AW, Orman JA: The epidemiology of traumatic brain injury. J Head Trauma Rehabil 2010, 25:72-80.

24. Hoane MR, Becerra GD, Shank JE, Tatko L, Pak ES, Smith M, Murashov AK: Transplantation of neuronal and glial precursors dramatically improves sensorimotor function but not cognitive function in the traumatically injured brain. J Neurotrauma 2004, 21:163-174.

25. Srivastava AS, Shenouda S, Mishra R, Carrier E: Transplanted embryonic stem cells successfully survive, proliferate, and migrate to damaged regions of the mouse brain. Stem Cells 2006, 24:1689-1694.

26. Riess P, Molcanyi M, Bentz K, Maegele M, Simanski C, Carlitscheck C, Schneider A, Hescheler J, Bouillon B, Schafer U, Neugebauer E: Embryonic stem cell transplantation after experimental traumatic brain injury dramatically improves neurological outcome, but may cause tumors. J Neurotrauma 2007, 24:216-225.

27. Molcanyi M, Riess P, Bentz K, Maegele M, Hescheler J, Schafke B, Trapp T, Neugebauer E, Klug N, Schafer U: Trauma-associated inflammatory response impairs embryonic stem cell survival and integration after implantation into injured rat brain. J Neurotrauma 2007, 24:625-637.

28. Hedlund E, Perlmann T: Neuronal cell replacement in Parkinson's disease. J Intern Med 2009, 266:358-371.

29. Sethi KD: The impact of levodopa on quality of life in patients with Parkinson disease. Neurologist 2010, 16:76-83.

30. Calabresi P, Di Filippo M, Ghiglieri V, Tambasco N, Picconi B: Levodopainduced dyskinesias in patients with Parkinson's disease: filling the benchto-bedside gap. Lancet Neurol 2010, 9:1106-1117.

31. Freed CR, Greene PE, Breeze RE, Tsai WY, DuMouchel W, Kao R, Dillon S, Winfield H, Culver S, Trojanowski JQ, Eidelberg D, Fahn S: Transplantation of embryonic dopamine neurons for severe Parkinson's disease. N Engl J Med 2001, 344:710-719.

32. Olanow CW, Goetz CG, Kordower JH, Stoessl AJ, Sossi V, Brin MF, Shannon KM, Nauert GM, Perl DP, Godbold J, Freeman TB: A double-blind controlled trial of bilateral fetal nigral transplantation in Parkinson's disease. Ann Neurol 2003, 54:403-414.

33. Olanow CW, Kordower JH, Lang AE, Obeso JA: Dopaminergic transplantation for Parkinson's disease: current status and future prospects. Ann Neurol 2009, 66:591-596.

34. Bjorklund LM, Sanchez-Pernaute R, Chung S, Andersson T, Chen IY, McNaught KS, Brownell AL, Jenkins BG, Wahlestedt C, Kim KS, Isacson O: Embryonic stem cells develop into functional dopaminergic neurons after transplantation in a Parkinson rat model. Proc Natl Acad Sci U S A 2002, 99:2344-2349.

35. Kim JH, Auerbach JM, Rodriguez-Gomez JA, Velasco I, Gavin D, Lumelsky N, Lee SH, Nguyen J, Sanchez-Pernaute R, Bankiewicz K, McKay R: Dopamine neurons derived from embryonic stem cells function in an animal model of Parkinson's disease. Nature 2002, 418:50-56.

36. Chiba S, Lee YM, Zhou W, Freed CR: Noggin enhances dopamine neuron 
production from human embryonic stem cells and improves behavioral outcome after transplantation into Parkinsonian rats. Stem Cells 2008 26:2810-2820

37. Roy NS, Cleren C, Singh SK, Yang L, Beal MF, Goldman SA: Functional engraftment of human ES cell-derived dopaminergic neurons enriched by coculture with telomerase-immortalized midbrain astrocytes. Nat Med 2006, 12:1259-1268.

38. Ben-Hur T, Idelson M, Khaner H, Pera M, Reinhartz E, Itzik A, Reubinoff BE: Transplantation of human embryonic stem cell-derived neural progenitors improves behavioral deficit in Parkinsonian rats. Stem Cells 2004, 22:1246-1255.

39. Cho MS, Lee YE, Kim JY, Chung S, Cho YH, Kim DS, Kang SM, Lee H, Kim MH, Kim JH, Leem JW, Oh SK, Choi YM, Hwang DY, Chang JW, Kim DW: Highly efficient and large-scale generation of functional dopamine neurons from human embryonic stem cells. Proc Natl Acad Sci U S A 2008, 105:3392-3397.

40. Kim DW, Chung S, Hwang M, Ferree A, Tsai HC, Park JJ, Nam TS, Kang UJ, Isacson O, Kim KS: Stromal cell-derived inducing activity, Nurr1, and signaling molecules synergistically induce dopaminergic neurons from mouse embryonic stem cells. Stem Cells 2006, 24:557-567.

41. Buytaert-Hoefen KA, Alvarez E, Freed CR: Generation of tyrosine hydroxylase positive neurons from human embryonic stem cells after coculture with cellular substrates and exposure to GDNF. Stem Cells 2004, 22:669-674.

42. Andre VM, Cepeda C, Levine MS: Dopamine and glutamate in Huntington's disease: A balancing act. CNS Neurosci Ther 2010, 16:163-178.

43. Gallina P, Paganini M, Lombardini L, Mascalchi M, Porfirio B, Gadda D, Marini M, Pinzani P, Salvianti F, Crescioli C, Bucciantini S, Mechi C, Sarchielli E, Romoli AM, Bertini E, Urbani S, Bartolozzi B, De Cristofaro MT, Piacentini S, Saccardi R, Pupi A, Vannelli GB, Di Lorenzo N: Human striatal neuroblasts develop and build a striatal-like structure into the brain of Huntington's disease patients after transplantation. Exp Neurol 2010, 222:30-41

44. Frank S, Biglan K: Long-term fetal cell transplant in Huntington disease: stayin' alive. Neurology 2007, 68:2055-2056

45. Rosser AE, Barker RA, Harrower T, Watts C, Farrington M, Ho AK, Burnstein RM, Menon DK, Gillard JH, Pickard J, Dunnett SB: Unilateral transplantation of human primary fetal tissue in four patients with Huntington's disease: NEST-UK safety report ISRCTN no 36485475. J Neurol Neurosurg Psychiatry 2002, 73:678-685.

46. Freeman TB, Cicchetti F, Hauser RA, Deacon TW, Li XJ, Hersch SM, Nauert GM, Sanberg PR, Kordower JH, Saporta S, Isacson O: Transplanted fetal striatum in Huntington's disease: phenotypic development and lack of pathology. Proc Natl Acad Sci U S A 2000, 97:13877-13882.

47. Song J, Lee ST, Kang W, Park JE, Chu K, Lee SE, Hwang T, Chung H, Kim M: Human embryonic stem cell-derived neural precursor transplants attenuate apomorphine-induced rotational behavior in rats with unilateral quinolinic acid lesions. Neurosci Lett 2007, 423:58-61.

48. Aubry L, Bugi A, Lefort N, Rousseau F, Peschanski M, Perrier AL: Striatal progenitors derived from human ES cells mature into DARPP32 neurons in vitro and in quinolinic acid-lesioned rats. Proc Natl Acad Sci U S A 2008, 105:16707-16712

49. Vazey EM, Dottori M, Jamshidi P, Tomas D, Pera MF, Horne M, Connor B: Comparison of transplant efficiency between spontaneously derived and noggin-primed human embryonic stem cell neural precursors in the quinolinic acid rat model of Huntington's disease. Cell Transplant 2010, 19:1055-1062

50. Mangialasche F, Solomon A, Winblad B, Mecocci P, Kivipelto M: Alzheimer's disease: clinical trials and drug development. Lancet Neurol 2010, 9:702-716.

51. Wang Q, Matsumoto Y, Shindo T, Miyake K, Shindo A, Kawanishi M, Kawai N, Tamiya T, Nagao S: Neural stem cells transplantation in cortex in a mouse model of Alzheimer's disease. J Med Invest 2006, 53:61-69.

52. Moghadam FH, Alaie H, Karbalaie K, Tanhaei S, Nasr Esfahani MH, Baharvand $H$ : Transplantation of primed or unprimed mouse embryonic stem cellderived neural precursor cells improves cognitive function in Alzheimerian rats. Differentiation 2009, 78:59-68

53. Webb AA, Ngan S, Fowler JD: Spinal cord injury I: A synopsis of the basic science. Can Vet J 2010, 51:485-492.

54. McDonald JW, Liu XZ, Qu Y, Liu S, Mickey SK, Turetsky D, Gottlieb DI, Choi DW: Transplanted embryonic stem cells survive, differentiate and promote recovery in injured rat spinal cord. Nat Med 1999, 5:1410-1412.

55. Hendricks WA, Pak ES, Owensby JP, Menta KJ, Glazova M, Moretto J, Hollis S, Brewer KL, Murashov AK: Predifferentiated embryonic stem cells prevent chronic pain behaviors and restore sensory function following spinal cord injury in mice. Mol Med 2006, 12:34-46.

56. Kimura H, Yoshikawa M, Matsuda R, Toriumi H, Nishimura F, Hirabayashi H, Nakase H, Kawaguchi S, Ishizaka S, Sakaki T: Transplantation of embryonic stem cell-derived neural stem cells for spinal cord injury in adult mice. Neurol Res 2005, 27:812-819.

57. Kumagai G, Okada Y, Yamane J, Nagoshi N, Kitamura K, Mukaino M, Tsuji O, Fujiyoshi K, Katoh H, Okada S, Shibata S, Matsuzaki Y, Toh S, Toyama Y, Nakamura M, Okano H: Roles of ES cell-derived gliogenic neural stem/ progenitor cells in functional recovery after spinal cord injury. PLoS One 2009, 4:e7706.

58. Matsuda R, Yoshikawa M, Kimura H, Ouji Y, Nakase H, Nishimura F, Nonaka J, Toriumi H, Yamada S, Nishiofuku M, Moriya K, Ishizaka S, Nakamura M, Sakaki $\mathrm{T}$ : Cotransplantation of mouse embryonic stem cells and bone marrow stromal cells following spinal cord injury suppresses tumor development. Cell Transplant 2009, 18:39-54

59. Howard MJ, Liu S, Schottler F, Joy Snider B, Jacquin MF: Transplantation of apoptosis-resistant embryonic stem cells into the injured rat spinal cord. Somatosens Mot Res 2005, 22:37-44.

60. Chen J, Bernreuther C, Dihne M, Schachner M: Cell adhesion molecule I1transfected embryonic stem cells with enhanced survival support regrowth of corticospinal tract axons in mice after spinal cord injury. J Neurotrauma 2005, 22:896-906.

61. Cao Q, Xu XM, Devries WH, Enzmann GU, Ping P, Tsoulfas P, Wood PM, Bunge $M B$, Whittemore SR: Functional recovery in traumatic spinal cord injury after transplantation of multineurotrophin-expressing glial-restricted precursor cells. J Neurosci 2005, 25:6947-6957.

62. Hamada M, Yoshikawa H, Ueda Y, Kurokawa MS, Watanabe K, Sakakibara M, Tadokoro M, Akashi K, Aoki H, Suzuki N: Introduction of the MASH1 gene into mouse embryonic stem cells leads to differentiation of motoneuron precursors lacking Nogo receptor expression that can be applicable for transplantation to spinal cord injury. Neurobiol Dis 2006, 22:509-522.

63. Harper JM, Krishnan C, Darman JS, Deshpande DM, Peck S, Shats I, Backovic S, Rothstein JD, Kerr DA: Axonal growth of embryonic stem cell-derived motoneurons in vitro and in motoneuron-injured adult rats. Proc Natl Acad SciUSA 2004, 101:7123-7128.

64. Salehi M, Pasbakhsh P, Soleimani M, Abbasi M, Hasanzadeh G, Modaresi MH, Sobhani A: Repair of spinal cord injury by co-transplantation of embryonic stem cell-derived motor neuron and olfactory ensheathing cell. Iran Biomed J 2009, 13:125-135.

65. Rossi SL, Nistor G, Wyatt T, Yin HZ, Poole AJ, Weiss JH, Gardener MJ, Dijkstra S, Fischer DF, Keirstead HS: Histological and functional benefit following transplantation of motor neuron progenitors to the injured rat spinal cord. PLoS One 2010, 5:e11852.

66. Thonhoff JR, Ojeda L, Wu P: Stem cell-derived motor neurons: applications and challenges in amyotrophic lateral sclerosis. Curr Stem Cell Res Ther 2009 4:178-199.

67. Kerr CL, Letzen BS, Hill CM, Agrawal G, Thakor NV, Sterneckert JL, Gearhart JD, All AH: Efficient differentiation of human embryonic stem cells into oligodendrocyte progenitors for application in a rat contusion model of spinal cord injury. Int J Neurosci 2010, 120:305-313.

68. Marques SA, Almeida FM, Fernandes AM, dos Santos Souza C, Cadilhe DV, Rehen SK, Martinez AM: Predifferentiated embryonic stem cells promote functional recovery after spinal cord compressive injury. Brain Res 2010, 1349:115-128

69. Erceg S, Ronaghi M, Oria M, Roselló MG, Aragó MA, Lopez MG, Radojevic I, Moreno-Manzano V, Rodríguez-Jiménez FJ, Bhattacharya SS, Cordoba J, Stojkovic M: Transplanted oligodendrocytes and motoneuron progenitors generated from human embryonic stem cells promote locomotor recovery after spinal cord transection. Stem Cells 2010, 28:1541-1549.

70. Cloutier F, Siegenthaler MM, Nistor G, Keirstead HS: Transplantation of human embryonic stem cell-derived oligodendrocyte progenitors into rat spinal cord injuries does not cause harm. Regen Med 2006, 1:469-479

71. Hatch MN, Nistor G, Keirstead HS: Derivation of high-purity oligodendroglial progenitors. Methods Mol Bio/ 2009, 549:59-75.

72. Keirstead HS, Nistor G, Bernal G, Totoiu M, Cloutier F, Sharp K, Steward O: Human embryonic stem cell-derived oligodendrocyte progenitor cel transplants remyelinate and restore locomotion after spinal cord injury. J Neurosci2005, 25:4694-4705.

73. Nistor GI, Totoiu MO, Haque N, Carpenter MK, Keirstead HS: Human embryonic stem cells differentiate into oligodendrocytes in high purity 
and myelinate after spinal cord transplantation. Glia 2005, 49:385-396

74. Sharp J, Frame J, Siegenthaler M, Nistor G, Keirstead HS: Human embryonic stem cell-derived oligodendrocyte progenitor cell transplants improve recovery after cervical spinal cord injury. Stem Cells 2010, 28:152-163.

75. Mayor S: First patient enters trial to test safety of stem cells in spinal injury. BMJ 2010, 341:c5724.

76. Johnson PJ, Parker SR, Sakiyama-Elbert SE: Fibrin-based tissue engineering scaffolds enhance neural fiber sprouting and delay the accumulation of reactive astrocytes at the lesion in a subacute model of spinal cord injury. J Biomed Mater Res A 2010, 92:152-163.

77. Johnson PJ, Tatara A, McCreedy DA, Shiu A, Sakiyama-Elbert SE: Tissueengineered fibrin scaffolds containing neural progenitors enhance functional recovery in a subacute model of SCl. Soft Matter 2010, 6:5127-5137.

78. Johnson PJ, Tatara A, Shiu A, Sakiyama-Elbert SE: Controlled release of neurotrophin-3 and platelet-derived growth factor from fibrin scaffolds containing neural progenitor cells enhances survival and differentiation into neurons in a subacute model of SCl. Cell Transplant 2010, 19:89-101.

79. Willerth SM, Arendas KJ, Gottlieb DI, Sakiyama-Elbert SE: Optimization of fibrin scaffolds for differentiation of murine embryonic stem cells into neural lineage cells. Biomaterials 2006, 27:5990-6003.

80. Willerth SM, Faxel TE, Gottlieb DI, Sakiyama-Elbert SE: The effects of soluble growth factors on embryonic stem cell differentiation inside of fibrin scaffolds. Stem Cells 2007, 25:2235-2244.

81. Willerth SM, Rader A, Sakiyama-Elbert SE: The effect of controlled growth factor delivery on embryonic stem cell differentiation inside fibrin scaffolds. Stem Cell Res 2008, 1:205-218.

82. Hatami M, Mehrjardi NZ, Kiani S, Hemmesi K, Azizi H, Shahverdi A, Baharvand $\mathrm{H}$ : Human embryonic stem cell-derived neural precursor transplants in collagen scaffolds promote recovery in injured rat spinal cord. Cytotherapy 2009, 11:618-630.

83. Thouas GA, Contreras KG, Bernard CC, Sun GZ, Tsang K, Zhou K, Nisbet DR Forsythe JS: Biomaterials for spinal cord regeneration: outgrowth of presumptive neuronal precursors on electrospun poly(epsilon)caprolactone scaffolds microlayered with alternating polyelectrolytes. Conf Proc IEEE Eng Med Biol Soc 2008, 2008:1825-1828.
84. Straley KS, Foo CW, Heilshorn SC: Biomaterial design strategies for the treatment of spinal cord injuries. J Neurotrauma 2010, 27:1-19.

85. Willerth SM, Sakiyama-Elbert SE: Approaches to neural tissue engineering using scaffolds for drug delivery. Adv Drug Deliv Rev 2007, 59:325-338.

86. Hu BY, Weick JP, Yu J, Ma LX, Zhang XQ, Thomson JA, Zhang SC: Neural differentiation of human induced pluripotent stem cells follows developmental principles but with variable potency. Proc Natl Acad Sc USA 2010, 107:4335-4340.

87. Miura K, Okada Y, Aoi T, Okada A, Takahashi K, Okita K, Nakagawa M, Koyanagi M, Tanabe K, Ohnuki M, Ogawa D, Ikeda E, Okano H, Yamanaka S: Variation in the safety of induced pluripotent stem cell lines. Nat Biotechno/ 2009 27:743-745.

88. Tsuji O, Miura K, Okada Y, Fujiyoshi K, Mukaino M, Nagoshi N, Kitamura K Kumagai G, Nishino M, Tomisato S, Higashi H, Nagai T, Katoh H, Kohda K, Matsuzaki Y, Yuzaki M, Ikeda E, Toyama Y, Nakamura M, Yamanaka S, Okano H: Therapeutic potential of appropriately evaluated safe-induced pluripotent stem cells for spinal cord injury. Proc Natl Acad Sci U S A 2010 107:12704-12709.

89. Wernig M, Zhao JP, Pruszak J, Hedlund E, Fu D, Soldner F, Broccoli V, Constantine-Paton $\mathrm{M}$, Isacson $\mathrm{O}$, Jaenisch R: Neurons derived from reprogrammed fibroblasts functionally integrate into the fetal brain and improve symptoms of rats with Parkinson's disease. Proc Natl Acad Sci U S A 2008, 105:5856-5861.

90. Vierbuchen T, Ostermeier A, Pang ZP, Kokubu Y, Sudhof TC, Wernig M: Direct conversion of fibroblasts to functional neurons by defined factors. Nature 2010, 463:1035-1041.

\section{doi:10.1186/scrt58}

Cite this article as: Willerth SM: Neural tissue engineering using embryonic and induced pluripotent stem cells. Stem Cell Research \& Therapy 2011, 2:17. 